Dicle Tıp Dergisi / Dicle Med J (2018) 45 (3) : 265-273

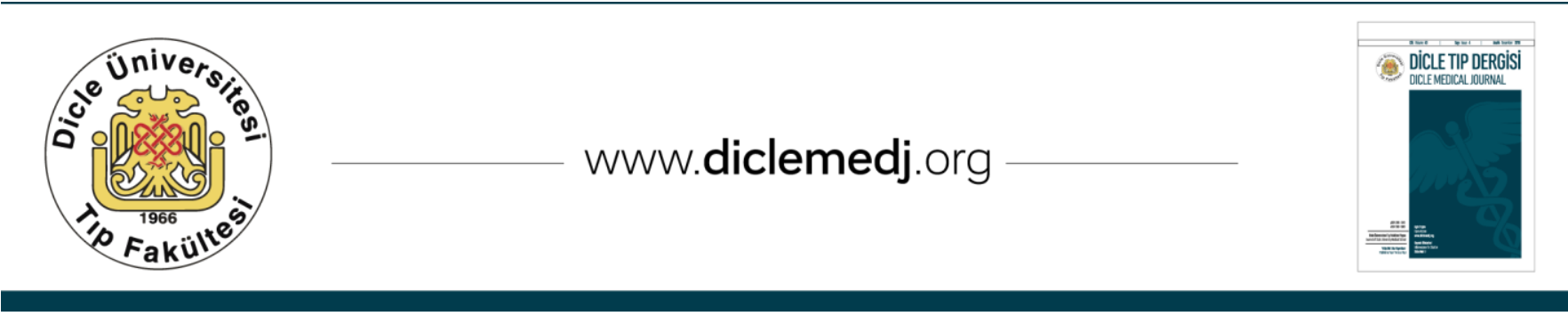

Özgün Araștırma / Original Article

\title{
Memenin Duktal Karsinoma in Situ Lezyonları: Histopatolojik özellikler ile p53, HER2/neu, bcl-2 ve PCNA Ekspresyonu arasındaki ilişki
}

\author{
Murat Tad ${ }^{1}$, Sezer Kulaçoğlu² \\ 1 Ahi Evran Üniversitesi Tıp Fakültesi Tıbbi Patoloji Anabilim Dall, Kirșehir, Türkiye ORCID: 0000-0003-2772-5856 \\ 2 Ankara Numune Eğitim ve Araştırma Hastanesi, Ankara, Türkiye ORCID: 0000-0003-3288-2039
}

Geliș: 10.01.2018, Revizyon: 23.07.2018, Kabul Tarihi: 01.08.2018

Öz

Amaç: Histopatolojik alt tip, nükleer derece ve komedonekroz memenin duktal karsinoma in situ (DKIS) lezyonları için önemli özelliklerdir. Bu çalışmanın amacı DKIS’nin histopatolojik özellikleri ile p53, HER2/neu, bcl-2 ve PCNA overekspresyonu arasındaki ilişskinin belirlenmesidir.

Yöntemler: DKIS tanısı almış 40 olgu immünohistokimyasal metodlar kullanılarak p53, HER2/neu, bcl-2 ve PCNA overekspresyonu açısından değerlendirildi. Düşük/ intermediate dereceli lezyonlar grup 1'e (düşük dereceli DKIS), yüksek dereceli olgular grup 2'ye (yüksek dereceli DKIS) dahil edildi. Ayrıca histolojik paternler değerlendirildi. Komedo tip ve non-komedo tip DKIS grupları oluşturuldu.

Bulgular: Toplam 40 olgunun 12'si yüksek dereceli, 28'i düşük dereceli, 8'i komedo tip ve 32'si non-komedo tip DKIS olarak belirlendi. Komedo tip DKIS olgularında sirasıyla \%37,5, \%62,5'inde p53 ve HER2/neu overekspresyonu izlenirken, non-komedo tip DKIS olgularında bu oran \% 6,5, \%3,1 idi. Yüksek dereceli olgularda sırasıyla \%41,7, \%50'sinde p53 ve HER2/neu overekspresyonu izlenirken, düşük dereceli olguların hiçbirinde p53 ve HER2/neu overekspresyonu gözlenmedi. Bcl-2 ile kuvvetli sitoplazmik boyanma yüksek dereceli olguların hiçbirinde izlenmezken, düşük dereceli olguların \%60'ında izlendi. Tüm bu overekspresyonlar için gruplar arasında istatistiksel olarak anlamlı fark vardı $(\mathrm{p}<0,05)$.

Sonuçlar: P53 ve HER2/neu overekspresyonu komedo tip ve yüksek derece gibi kötü prognostik faktörlerle ilişkili bulundu. Bcl-2 ile kuvvetli sitoplazmik boyanma non-komedo tip ve düşük derece gibi iyi prognostik faktörlerle ilișkili bulundu. Bu sonuçlar farklı biyolojik davranışa sahip DKIS alt tiplerinin tanımlanmasına katkı sağlayacaktır.

Anahtar Kelimeler: Duktal karsinoma in situ, meme kanseri, p53, HER2/neu, bcl-2.

DOI: $10.5798 /$ dicletip. 457239

Yazışma Adresi / Correspondence: Murat Tad, Ahi Evran Üniversitesi Eğitim ve Araştırma Hastanesi Patoloji Bölümü, Kırşehir, Türkiye e-mail: murattad@yahoo.com 


\title{
Ductal carcinoma in situ lesions of the breast: correlation between histopathologic features and p53, HER2/neu, bcl-2 and PCNA expression
}

\begin{abstract}
Objective: The histopathological subtype, nuclear grade and comedonecrosis are important features for ductal carcinoma in situ (DCIS) of the breast. The aim of this study was to determine correlation between histopathologic properties of DCIS and p53, HER2/neu, bcl-2 and PCNA overexpression.

Method: We evaluated 40 cases of DCIS for p53, HER2/neu, bcl-2 and PCNA overexpression by using immunohistochemical methods. We divided lesions into two groups. Low/intermediate grade DCIS cases were included in group 1 (low grade DCIS) and high grade DCIS were included in group 2 (high grade DCIS). Histologic paterns were also evaluated. Comedo type and non-comedo type DCIS groups were formed.

Results: A total of 40 DCIS including 12 high grade, 28 low grade, 8 comedo type and 32 non-comedo type were revealed. P53 and HER2/neu overexpressions were seen 37,5\%, 62,5\% in comedo type DCIS and 6,5\%, 3,1\% in noncomedo type DCIS, respectively. P53 and HER2/neu overexpressions were not seen in low grade DCIS and were seen $41,7 \%$ and $50 \%$ in high grade DCIS, respectively. Strong cytoplasmic staining with bcl-2 was not seen in high grade DCIS and was seen $60 \%$ in low grade DCIS. There was significant difference statistically between groups for all of these overexpressions $(\mathrm{p}<0,05)$.

Conclusions: P53 and HER/neu overexpressions were associated with poor prognostic factors such as comedo type and high grade. Strong cytoplasmic bcl-2 staining was associated with good prognostic factors such as non-comedo type and low grade. These results contribute to define DCIS subtypes that have different biological behaviour.
\end{abstract}

Keywords: Ductal carcinoma in situ, breast cancer, p53, HER2/neu, bcl-2.

\section{GİRIŞ}

Duktal karsinoma in situ (DKIS) meme kanserinin tanınabilen en erken evresidir ve invaziv kansere dönüştüğü görüşü yaygın olarak kabul görmektedir. Meme tümörlerinin heterojenitesi ve meme lezyonlarının karmaşıklığı, meme dokusundaki genetik değişikliklerin, bunların meme karsinogenezindeki etkilerinin ve meme karsinogenezine dahil olma zamanlarının daha iyi anlaşılması ihtiyacını ortaya çıkarmaktadır ${ }^{1-}$ 3. P53 mutasyonları kanserlerde görülen genetik değişikliklerden en sık görüleni olup meme kanserinin prognozu ve karsinogenezi ile ilişkili olduğu varsayllır ${ }^{4,5}$. Meme tümörlerinde p53 tümör süpresör geninde mutasyon sıktır ancak bunun meme kanseri gelişimindeki etkisi hala tam olarak anlaşılamamıştır. P53 mutasyonları, meme kanseri gelişiminde prekürsör kabul edilen memenin DKIS ve atipik duktal hiperplazisinde izlenir. P53 mutasyonlarının, invaziv meme tümörlerinde sıklıkla bulunduğu ve meme kanseri gelişiminde etkili olduğu bilindiği halde, bu mutasyonların preinvaziv meme lezyonlarında araştırıldığı çalışmalar az sayıdadır ${ }^{6,7}$. HER2/neu amplifikasyonu asıl olarak meme karsinogenezinin başlangıcında ortaya çıkar. Hayvanlarda yapılan çalışmalar ve in vitro çalışmalar HER2/neu overekspresyonunun kanserin sonucundan çok sebebi olduğunu göstermektedir ${ }^{8-10}$. Son yıllarda tümör oluşumunda apoptozisin rolüne ilgi artmaktadır. Apoptozisi regüle eden birçok genetik faktör gösterilmiştir. Bu faktörler arasındaki ilişki oldukça komplekstir ve tam olarak tanımlanamamıştır ${ }^{11,12}$. Bcl-2 protein ekspresyonu invaziv meme kanserlerinin \%5880'inde izlenir ve düşük histolojik derece, düşük proliferasyon hızı, östrojen ve progesteron reseptör pozitivitesi gibi iyi prognostik faktörlerle birliktelik gösterir ${ }^{13,14}$. PCNA DNA sentezi için özel, nükleer bir proteindir. Primer olarak nükleusta, hücre siklusunun S fazında ortaya çıkar. Yüksek PCNA 
skoru kötü prognozun bir göstergesidir3,15,16. Meme kanserlerinde de proliferasyon indeksi prognoz ve tedavide önemlidir. İmmünhistokimyasal olarak skorlanmış PCNA meme kanserinin prognostik faktörlerindendir. Bir çalışma PCNA'nın tümör boyutu ve histolojik derecesi ile anlamlı korelasyon gösterdiğini rapor etmiştir ${ }^{17}$. Biz p53, HER2/neu, bcl-2 ve PCNA overekspresyonunun DKIS'nin histopatolojik özellikleri (histopatolojik alt tip, derece ve komedo nekroz varlığı) ile ilişkisini açığa kavuşturmak istedik.

\section{YÖNTEMLER}

$\mathrm{Bu}$ çalışma retrospektif bir çalışmadır. Çalışmaya 2001 ile 2007 yılları arasında Ankara Numune Eğitim ve Araştırma Hastanesi Patoloji Bölümü'ne gelen meme biyopsi materyallerinden DKIS tanısı almış 40 olgu dahil edildi. Daha önce DKÍS veya invaziv dukatal karsinoma tanısı alarak cerrahi müdahale, kemoterapi veya radyoterapi uygulanmış olgular, parafin bloklarında uygun inceleme yapmak için yeterli doku bulunmayan olgular ve DKİS birlikteliğinde lobüler karsinoma in situ, kronik inflamasyon, granülomatöz mastitis veya yağ nekrozu bulunan olgular çalışma dışı bırakıldı. Çalışma Helsinki Bildirgesi'ne sadık kalınarak gerçekleştirilmiştir. Olguların yaşları 25 ile 76 arasında olup ortalama yaş 50.08 olarak saptand. Olgulara ait parafin bloklar ve lamlar arşivden çıkarılarak yeniden değerlendirildi. Olgulara ait tüm lamlar tek tek incelenerek tümörü en iyi temsil ettiği düşünülen bloklar belirlendi. Seçilen her bir bloktan dörder boyasız kesit alınarak immünohistokimyasal yöntemler kullanılarak p53, HER2/neu, bcl-2 ve PCNA çalışıldı.

DKIS olguları Holland ve ark.'nın ortaya koyduğu kriterler kullanılarak derece 1 (düşük dereceli/iyi diferansiye), derece 2 (intermediate dereceli/orta derecede diferansiye) ve grade 3 (yüksek dereceli/az diferansiye) olarak üç kategoriye ayrıldı. Daha sonra düşük dereceli (düşük/intermediade derece) ve yüksek dereceli DKIS olmak üzere 2 grup oluşturuldu. Ayrıca komedonekroz varlığı ve histolojik paternler değerlendirildi. Birden fazla paternin gözlendiği olgularda en yaygın patern dikkate alındı. Olgular komedo ve nonkomedo olmak üzere 2 gruba ayrıldı. İmmünhistokimyasal boyama için, \% 10’luk formalinde fikse edilmiş ve parafine gömülmüş bloklardan 3-4 mikron kalınlığında kesitler adezivli lamlara alındı. Lamlar etüvde bekletildikten sonra 3'er dakika, ksilol ve sırası ile \% 96, \%80, \% 75, \% 70’lik alkollerden geçirilerek deparafinize ve dehidrate edildi. Fosfat buffer salinde (PBS) 6 dakika bekletildi. $\% \quad$ 3'lük H2O2 solüsyonunda 10 dakika bekletildi. Distile suda 3 kez yıkandıktan sonra sitrat buffer solüsyonu içinde mikrodalga fırına konarak 2 kez 7'şer dakika kaynatıldı. Sonra oda ısısında soğumaya birakılan preparatlar, PBS'de biraz bekletildi. Aynı bloktan alınan seri kesitlere monoklonal mouse anti-human p53 (klon D0-7 DAKO), bcl-2 (klon 100/D5 DAKO), HER2/neu (klon CB11 DAKO) ve PCNA (klon PC10 DAKO) primer antikorları damlatılarak oda isısında 45 dakika bekletildi. Sonra 2 kez 3 dakika PBS ile muamele edildi. Kullanılan boya setinin prosedürüne uygun olarak link, label ve kromojen damlatılarak etüvde gerekli sürelerde bekletildi. Her basamak arasında 2 kez 3'er dakika PBS'de bekletildi. Lamlara kontrast boyama için Mayer Hematoksilen damlatılarak bekletildikten sonra preparatlar musluk suyunda yıkandı. Mounting medium ile üzeri kapatıldı ve kuruduktan sonra ışık mikroskobunda incelendi. Pozitif kontrol olarak p53 ve, HER2/neu için yaygın ve kuvvetli boyanmanın izlendiği meme karsinomu olgularl, bcl-2 ve PCNA için ise lenfoid hiperplazi gösteren tonsil dokusu kullanıldı. P53 ve PCNA için nükleer, bcl-2 için sitoplazmik, HER2/neu için sitoplazmik membran boyanması dikkate alındı.

İmmünreaksiyona semikantatif olarak p53, bcl2 ve PCNA için tümör hücrelerinin boyanma 
yüzdelerine bakılarak 5'li skala uygulandı. Buna göre;

0 = Boyanma yok veya pozitif boyanan tümör hücresi oranı $\% 1$ 'den az olması

1 = Pozitif boyanan tümör hücresi oranı \%1-10 olmasi

2 = Pozitif boyanan tümör hücresi oranı \%1125 olması

3 = Pozitif boyanan tümör hücresi oranı \%2650 olması

4 = Pozitif boyanan tümör hücresi oranı \%51100 olması

P53 ve bcl-2 için \% 10'un üzerindeki boyanma (skor 2, 3 ve 4), PCNA için \% 25'in üzeri (skor 3 ve 4) overekspresyon olarak kabul edildi. Bcl-2 için sitoplazmik boyanma yoğunluğu da değerlendirilerek boyanma izlenmeyen, zayıf boyanma izlenen ve kuvvetli boyanma izlenen olgular belirlendi. Bcl-2 ile sitoplazmik boyanma saptanan olgulardan kuvvetli boyanma izlenen olgularla zayıf boyanma izlenen olgular karşılaştırıldı.

HER2/neu ise;

$0=$ Hücrelerin sitoplazmik membranlarında boyanma yok veya \% 10'undan azında boyanma var

1 = Tümör hücrelerinin \% 10'undan fazlasında sitoplazmik membranın bir kısmında boyanma var

2 = Tümör hücrelerinin \% 10'undan fazlasında sitoplazmik membranın tamaminda hafif boyanma var

3 = Tümör hücrelerinin \% 10'undan fazlasında sitoplazmik membranın tamamında kuvvetli boyanma var

HER2/neu için skor 2 ve 3 overekspresyon kabul edildi.

P53, HER2/neu, bcl-2 ve PCNA overekspresyonu ve bcl-2 ile kuvvetli sitoplazmik boyanma izlenen olgular tespit edildi. Bunların histopatolojik patern, derece ve komedo nekroz ile ilişkileri araștırıldı. İmmünohistokimyasal çalışmalar sırasında p53 ve bcl-2 için kesit alınırken 1'er olguda blokta DKIS alanı kalmadığı için değerlendirme yapılamadı.
İstatistiksel Analiz

Verilerin analizi SPSS 11.5 paket programında yapıldı. Tanımlayıcı istatistikler sürekli değişkenler ortalama \pm std. sapma biçiminde, kategorik değişkenler yüzde (\%) şeklinde gösterildi. Gruplar arasında ortalamalar yönünden farkın anlamlllı̆̆ Mann Whitney U testiyle değerlendirildi. Kategorik karşılaştırmalar için Khi-Kare veya Fisher'in Kesin testi kullanıldı. p<0,05 için sonuçlar istatistiksel olarak anlamlı kabul edildi. Farklı paternler, farklı dereceliler ve komedo nekroz varlığı/yokluğu arasındaki ekspresyon farklılığı incelendi.

\section{BULGULAR}

Toplam 40 olgunun 12'si yüksek dereceli, 8'i komedo tip DKIS olarak belirlendi. Komedo tip DKIS olgularının \%37,5'inde (8 olgunun 3'ünde) p53 overekspresyonu izlenirken nonkomedo DKIS olgularinda bu oran sadece $\% 6,5$ (31 olgunun 2'sinde) idi ve bu fark istatistiksel olarak anlamlıydı $(\mathrm{p}=0,049)$. Komedo tip DKIS olgularının \% 62,5'inde (8 olgudan 5'inde) HER2/neu overekspresyonu izlenirken nonkomedo DKIS olgularının oluşturduğu grupta bu oran sadece \%3,1 (32 olgudan 1'inde) idi ve bu fark istatistiksel olarak anlamlıydı $(\mathrm{p}<0,001)$. Komedo tip DKIS olgularının \%37,5'inde (8 olgudan 3'ünde) bcl-2 overekspresyonu izlenirken non-komedo tip DKIS olgularının oluşturduğu grupta bu oran $\% 58,1$ (31 olgudan 18'inde) idi ve bu fark istatistiksel olarak anlaml olmamakla birlikte bcl-2 overekspresyonu non-komedo tip DKIS olgularında daha yüksek oranda izlendi. Komedo tip DKIS olgularının hiçbirinde bcl-2 ile kuvvetli sitoplazmik boyanma izlenmezken, non-komedo tip DKIS olgularının \%29'unda kuvvetli sitoplazmik boyanma gözlendi. PCNA overekspresyonu komedo tip DKIS'lerin tamaminda saptanırken, non-komedo tip DKIS'lerin \%75'inde (32 olgunun 8'inde) izlendi. Komedo ve non-komedo tip DKIS olgularına ait immünohistokimyasal bulgular Tablo 1'de verilmiştir. 
Tablo 1: Komedo ve nonkomedo tip DKIS olguları arasında overekspresyonunun değerlendirilmesi

\begin{tabular}{|c|c|c|c|c|}
\hline Antikor & $\begin{array}{c}\text { 0ver- } \\
\text { ekspresyon }\end{array}$ & $\begin{array}{c}\text { Nonkomedo } \\
n(\%)\end{array}$ & $\begin{array}{l}\text { Komedo } \\
\text { n (\%) }\end{array}$ & $\mathrm{P}$ değeri \\
\hline \multirow{2}{*}{ P53 } & - & $29(\% 93,5)$ & $5(\% 62,5)$ & \multirow{2}{*}{0,049} \\
\hline & + & $2(\% 6,5)$ & $3(\% 37,5)$ & \\
\hline \multirow[b]{2}{*}{ HER2/neu } & - & $31(\% 96,9)$ & $3(\% 37,5)$ & \multirow[b]{2}{*}{$<0,001$} \\
\hline & + & $1(\% 3,1)$ & $5(\% 62,5)$ & \\
\hline \multirow{2}{*}{ Bcl-2 } & - & $13(\% 41,9)$ & $5(\% 62,5)$ & \multirow{2}{*}{0,432} \\
\hline & + & $18(\% 58,1)$ & $3(\% 37,5)$ & \\
\hline \multirow{2}{*}{ PCNA } & - & $8(\% 25)$ & $0(\% 0)$ & \multirow{2}{*}{0,173} \\
\hline & + & $24(\% 75)$ & $8(\% 100)$ & \\
\hline
\end{tabular}

Yüksek dereceli olguların \%41,7'sinde (12 olgudan 5'inde) p53 overekspresyonu izlenirken düşük dereceli olguların hiçbirinde p53 overekspresyonu gözlenmedi (Resim 1). $\mathrm{Bu}$ fark istatistiksel olarak anlamlı bulundu $(\mathrm{p}<0,001)$. Düşük dereceli olguların hiçbirinde HER2/neu overekspresyonu izlenmezken yüksek dereceli olguların \%50'sinde gözlendi ve bu fark istatistiksel olarak anlamlı bulundu ( $\mathrm{p}<0,001)$ (Resim 1). Düşük dereceli olgularda bcl-2 overekspresyonu \%55,6 (27 olgunun 15 'inde) iken, yüksek dereceli olgularda bu oran \%50 (12 olgunun 6'sında) idi. Bcl-2 ile kuvvetli sitoplazmik boyanma yüksek dereceli olguların hiçbirinde izlenmezken, düşük dereceli olguların \%60'ında izlendi (Resim 1).

Düşük ve yüksek dereceli olgular arasındaki bu fark istatistiksel olarak anlamlı bulundu $(\mathrm{p}=0,019)$. Yüksek dereceli olguların tamaminda (12 olgu) PCNA overekspresyonu izlenirken, düşük dereceli olgularda bu oran \%71,4 (28 olgunun 20'sinde) idi (Resim 1). Yüksek dereceli ve düşük dereceli DKíS olgularına ait immünohistokimyasal bulgular Tablo 2 ve Tablo 3'te verilmiștir.

Tablo 2: Düşük ve yüksek dereceli DKİS olguları arasında overekspresyonun değerlendirilmesi

\begin{tabular}{|c|c|c|c|c|}
\hline \multirow{2}{*}{ Antikor } & $\begin{array}{c}\text { 0ver- } \\
\text { ekspresyon }\end{array}$ & $\begin{array}{c}\text { Düşük } \\
\text { derece } \\
\mathrm{n}(\%)\end{array}$ & $\begin{array}{c}\text { Yüksek } \\
\text { derece } \\
\mathrm{n}(\%)\end{array}$ & \multirow{2}{*}{ P değeri } \\
\hline \multirow{2}{*}{ P53 } & - & $27(\% 100)$ & $7(\% 58,3)$ & \multirow{2}{*}{$<0,001$} \\
\cline { 2 - 4 } & + & $0(\% 0)$ & $5(\% 41,7)$ & \\
\cline { 2 - 4 } HER2/neu & + & $28(\% 100)$ & $6(\% 50)$ & \multirow{2}{*}{$<0,001$} \\
\cline { 2 - 4 } Bcl-2 & - & $12(\% 44,4)$ & $6(\% 50$ & \multirow{2}{*}{0,748} \\
\cline { 2 - 4 } & + & $15(\% 55,6)$ & $6(\% 50$ & \multirow{2}{*}{0,079} \\
\hline \multirow{2}{*}{ PCNA } & - & $8(\% 28,6)$ & $0(\% 0)$ & \multicolumn{2}{|c|}{$6(\% 50)$} & \\
\cline { 2 - 4 } & + & $20(\% 71,4)$ & $12(\% 100)$ & \\
\hline
\end{tabular}

Sonuç olarak P53 ve HER-2/neu overekspresyonu, istatistiksel olarak anlamlı olacak şekilde, komedo tip ve yüksek dereceli DKIS olgularında daha yüksekti. Düşük dereceli olguların hiçbirinde p53 ve HER-2/neu overekspresyonu izlenmedi (Figür 1-2). Bcl-2 ile kuvvetli sitoplazmik boyanma sadece düşük dereceli ve non-komedo tip olgularda izlendi (Figür 3). Düşük ve yüksek dereceli olgular arasındaki fark istatistiksel olarak anlamlı bulundu. İstatistiksel olarak anlamlı olmamakla birlikte bcl-2 overekspresyonu düşük dereceli ve non-komedo tip DKIS olgularmda, PCNA ile yüksek proliferasyon indeksi yüksek grade'li ve komedo tip DKIS olgularında daha fazla izlendi. Ancak bcl-2 overekspresyonu açısından düşük ve yüksek dereceli olgular arasında ki fark azdı (\%55,6'ya karşı \%50). P53, HER2/neu, bcl-2 ve PCNA overekspresyonu aynı anda 3 olguda, p53, bcl-2 ve PCNA overekspresyonu aynı anda 1 olguda izlendi. Bu olguların 4'ü de yüksek dereceli idi. 
Tablo 3: Bcl-2 pozitif düşük dereceli ve yüksek dereceli olgular arasında bcl-2 boyanma yoğunluğunun değerlendirilmesi

\begin{tabular}{|c|c|c|c|c|c|c|}
\hline \multirow{2}{*}{ Bcl-2 boyanma yoğunluğu } & \multicolumn{2}{|c|}{ Düşük derece (n=15) } & \multicolumn{2}{|c|}{ Yüksek derece $(n=6)$} & \multicolumn{2}{|c|}{ Toplam $(\mathrm{N}=21)$} \\
\hline & Sayl & $\%$ & Sayl & $\%$ & Sayl & $\%$ \\
\hline Zayıf & 6 & 40,0 & 6 & 100,0 & 12 & 57,1 \\
\hline Kuvvetli & 9 & 60,0 & 0 & 0,0 & 9 & 42,9 \\
\hline
\end{tabular}
$\mathrm{p}=0,019$

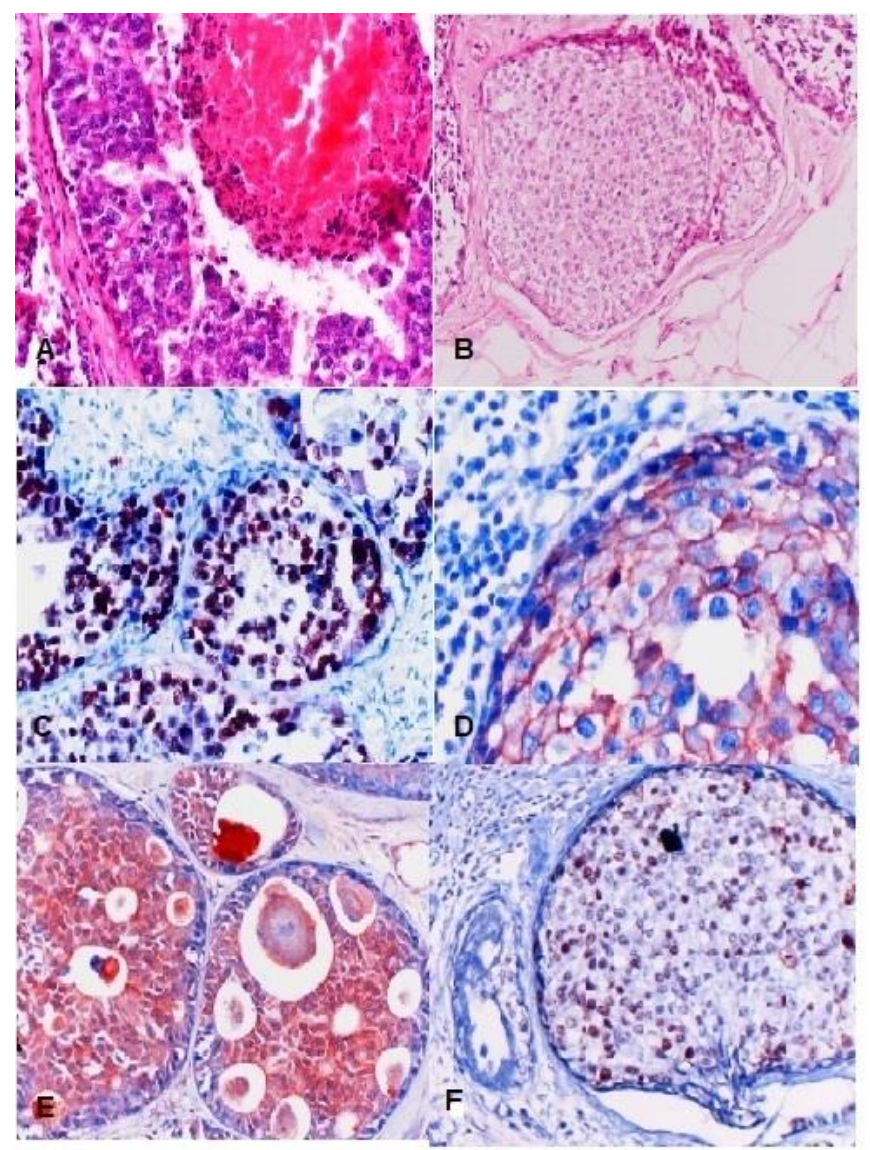

Resim 1. Yüksek dereceli/komedo tip (A), düşük dereceli/solid tip DKIS (B), P53 (C), HER2/neu (D), Bcl-2 (E) ve PCNA (F) ile immünohistokimyasal boyanma. A, Yüksek dereceli/komedo tip DKIS (H\&E, x400). B, Düşük dereceli/solid tip DKIS (H\&E, $\mathrm{x} 100)$. C, P53 ile yaygın kuvvetli nükleer boyanma (x200). D, HER2/neu ile yaygin, kuvvetli sitoplazmik membran boyanması (x400). E, Bcl-2 ile yaygın, kuvvetli sitoplazmik boyanma (x200). F, PCNA ile yaygın nükleer boyanma (x200).

Olguların 15'i kribriform, 14'ü solid, 8'i komedo tip DKIS olup, mikropapiller, berrak hücreli ve "clinging" DKIS 1'er olguda izlendi. Bu sayllar istatistiksel açıdan yetersiz olduğundan histolojik paternler hakkında analiz yapmak mümkün olmadl.

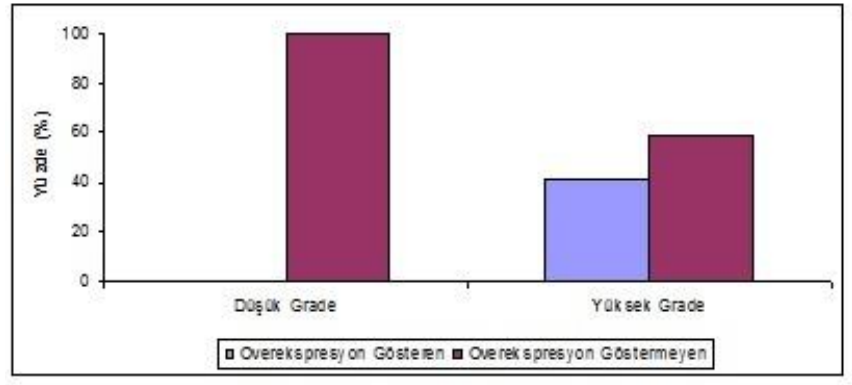

Figür 1. Düşük dereceli ve yüksek dereceli olgular arasında p53 overekspresyonun değerlendirilmesi

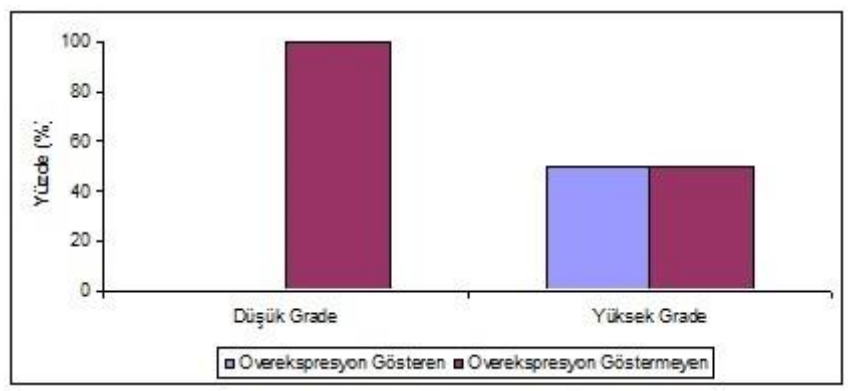

Figür 2. Düşük dereceli ve yüksek dereceli olgular arasında HER2/neu overekspresyonunun değerlendirilmesi

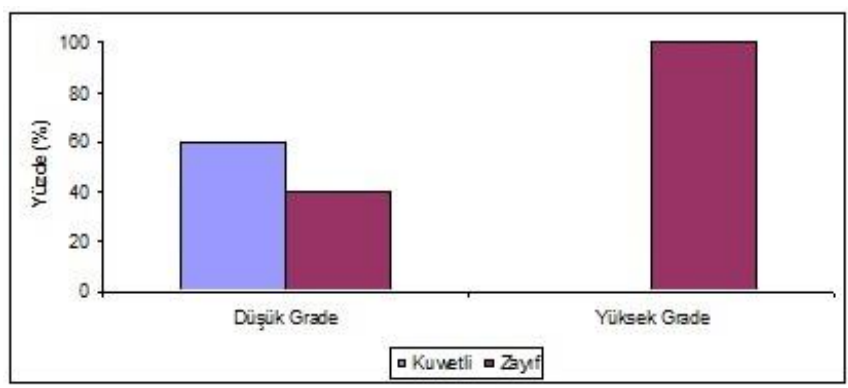

Figür 3. Düşük dereceli ve yüksek dereceli olgular arasında bcl2 boyanma yoğunluğunun değerlendirilmesi 


\section{TARTIŞMA}

P53 mutasyonları kanserlerde görülen genetik değişikliklerden en sık görüleni olup meme kanserinin prognozu ve karsinogenezi ile ilişkili olduğu varsayılır. P53 protein ekspresyonu sıklıkla yüksek dereceli veya komedo tip DKIS olgularında izlenirir,4,5. Bu çalıșmada komedo tip DKIS olgularının \%37,5'inde p53 overekspresyonu izlenirken, non-komedo DKIS olgularında bu oran sadece $\% 6,5$ idi ve bu fark istatistiksel olarak anlamliydı $(\mathrm{p}=0,049)$. Yüksek dereceli olguların \%41,7'sinde p53 overekspresyonu izlenirken düşük dereceli olguların hiçbirinde p53 overekspresyonu gözlenmedi. Bu fark istatistiksel olarak anlamlı bulundu ( $\mathrm{p}=0,001)$.

Leal ve ark.'nın komedo tip ve yüksek dereceli DKIS için daha yüksek, intermediate/düşük dereceli DKIS için ise daha düşük HER2/neu ekspresyonu buldukları bildirilmiștir ${ }^{18}$. Bizim çalışmamızda komedo tip DKIS olgularının \%62,5'inde HER2/neu overekspresyonu izlenirken, non-komedo DKIS olgularının olușturduğu grupta bu oran sadece $\% 3,1$ idi ve bu fark istatistiksel olarak anlamlıdı $(p<0,001)$. Nekrozsuz non-komedo DKIS için en düşük, nekrozlu non-komedo DKIS için intermediate ve komedo DKIS için en yüksek HER2/neu pozitivitesi bildirilmiştir (18). Bizim çalışmamızdan elde edilen sonuçlar bu bulgularla uyumluydu ve komedo tip DKIS olgularının \%62,5'inde HER2/neu overekspresyonu izlenirken non-komedo DKIS olgularının oluşturduğu grupta bu oran sadece $\% 3,1$ 'di ve bu fark istatistiksel olarak anlamlıyd $(\mathrm{p}<0,001)$.

HER2/neu overekspresyonu ile agresif biyolojik davranış ve az diferansiye DKIS arasında güçlü korelasyon bulunduğu bildirilmiştirir-20. Biz bu çalışmada Holland ve ark.'nın kriterlerine göre olguları sınıflandırdık ve buna göre toplam 40 olgunun 12'si yüksek dereceli (az diferansiye), 28'i düşük/intermediate dereceli olarak sınıflandırıldı. Yüksek dereceli olguların \%50'sinde HER2/neu overekspresyonu izlerken, düşük/intermediate dereceli olguların hiçbirinde overekspresyon izlemedik ve bu fark istatistiksel olarak anlamlı bulundu $(\mathrm{p}<0,001)$.

Bcl-2 protein ekspresyonu düşük histolojik derece, düşük proliferasyon hızı, östrojen ve progesteron reseptör pozitivitesi, düşük EGFR, düşük HER2/neu ekspresyonu gibi iyi prognostik faktörlerle birliktelik gösterir13,14,21,22. Komedo tip DKIS olgularının \%37,5'inde bcl-2 overekspresyonu izlenirken non-komedo tip DKIS olgularının oluşturduğu grupta bu oran \%58,1 (31 olgudan 18'inde) idi ve bu fark istatistiksel olarak anlaml olmamakla birlikte bcl-2 overekspresyonu nonkomedo tip DKIS olgularında daha yüksek oranda izlendi. Düşük dereceli olgularda ise bcl-2 overekspresyonu \%55,6 (27 olgunun 15 'inde) iken, yüksek dereceli olgularda bu oran daha düşüktü ve $\% 50$ olarak belirlendi.

Bcl-2 overekspresyonu izlediğimiz olgularda skoru dikkate almaksızın sitoplazmik boyanma yoğunluğuna göre olguları kuvvetli ve zayıf ekspresyon gösterenler olarak iki gruba ayırdık. Buna göre bcl-2 pozitif olgular içerisinde kuvvetli sitoplazmik boyanma sadece düşük dereceli olgularda (15 olgunun 9'unda, \%60) izlendi. Yüksek dereceli olguların hiçbirinde bcl-2 ile kuvvetli sitoplazmik boyanma gözlenmedi. Düşük dereceli ve yüksek dereceli olgular arasındaki bu fark istatistiksel olarak anlamlı idi $(\mathrm{p}=0,019)$.

PCNA DNA sentezi için özel, nükleer bir proteindir. Primer olarak nükleusta, hücre siklusunun S fazında ortaya çıkar. Meme lezyonlarının proliferarasyon aktivitelerini ölçmede iyi bir belirteç olup yüksek PCNA skoru kötü prognozun bir göstergesidir $3,15,16$. Çalışmamızda PCNA overekspresyonu toplam 40 DKIS olgusunun 32'sinde (\%80) izlendi. Komedo tip DKIS'lerin tamaminda $(8 / 8, \% 100)$ PCNA overekspresyonu izlenirken, nonkomedo DKIS olgularında bu oran \%75 (24/32) 
idi. Yüksek dereceli olguların tamamında (12/12, \%100) PCNA overekspresyonu izlenirken, düşük dereceli olgularda bu oran $\% 71,4 \quad(20 / 28)$ idi. Bu farklar istatistiksel olarak anlamlı olmamakla birlikte yüksek dereceli ve komedo tip DKIS olgularında PCNA overekspresyonu daha yüksekti.

Bizim çalışmamızda P53 ve HER2/neu overekspresyonu yüksek derece ve komedo nekroz varlığı gibi kötü prognostik özelliklerle, bcl-2 ile kuvvetli sitoplazmik boyanma iyi prognostik özelliklerden olan düşük derece ile birliktelik gösterdi. Bcl-2 overekspresyonu düşük derece ve non-komedo tip DKIS olgularında, PCNA ile yüksek proliferasyon indeksi yüksek derece ve komedo nekoz varlığında daha yüksek orana sahipti.

$\mathrm{Bu}$ çalışma ile DKİS'nin prognozu açısından önemli farklı bazı immünhistokimyasal özellikler, istatistiksel olarak anlamlı olacak şekilde, ortaya konuldu. Ancak histolojik paternler hakkında analiz yapmak için olgu sayısı yetersiz olduğundan bu konuda analiz yapmak mümkün olmadı. Sonuçlarımız daha fazla sayıda olgu dahil edilerek yapılacak çalışmalarla desteklenmelidir. Ayrıca bu konu ile ilgili olarak gerçekleştirilecek prospektif çalışmalar DKİS'nin farklı özelliklere sahip alt tiplerinin ortaya konularak kişiye özel tedavi seçeneklerinin geliştirilmesine önemli katkılar sağlayacaktır.

Sonuçlar gösterdi ki; p53 ve HER2/neu overekspresyonu kötü prognozla birliktelik gösterirken, bcl-2 ile kuvvetli sitoplazmik boyanma iyi prognozla birliktelik göstermektedir. İleride yapılacak birçok çalışma ile preinvaziv evrede bunların ve daha başka değişikliklerin tespit edilmesi meme kanseri patogenezinin daha iyi anlaşılması ve farklı biyolojik davranışa sahip DKIS alt tiplerin tanımlanması ile sonuçlanabilir.

Bu çalışma 25. Ulusal Patoloji Kongres'nde (1417 Ekim 2015, Bursa) poster olarak sunulmuştur.
Çıkar Çatışması Beyanı: Yazarlar çıkar çatışması olmadığını bildirmişlerdir.

Finansal Destek: Bu çalışma herhangi bir fon tarafından desteklenmemiştir.

Declaration of Conflicting Interest: The authors declare that they have no conflict of interest.

Financial Disclosure: No financial support was received.

\section{KAYNAKLAR}

1. Perez AA, Balabram D, Salles MA, Gobbi H. Ductal carcinoma in situ of the breast: correlation between histopathological features and age of the patients. Diagn Pathol. 2014; 9: 227-32.

2. Shan M, Zhang X, Liu X, et al. P16 and p53 play Distinct roles in different subtypes of breast cancer. PLoS One 2013; 8: e76408.

3. Terry G, Ho L, Londesborough P, Duggan C, Hanby A, Cuzick J. The expression of FHIT, PCNA and EGFR in benign and malignant breast lesions. Br J Cancer 2007 Jan 15; 96: 110-7.

4. Tunon G, Ricote M, Ruiz A, et al. Cell cycle control related proteins (p53, p21, and $\mathrm{Rb}$ ) and transforming growth factor B (TGFB) in benign and carcinomatous (in situ and infilrating) human breast: implications in malignant transformations. Cancer Invest 2006; 24: 119-25.

5. Mylonas I, Makovitzky J, Jeschke U, Briese V, Friese K, Gerber B. Expression of Her2/neu, steroid receptors (ER and PR), Ki67 and p53 in invasive mammary ductal carcinoma associated with ductal carcinoma in situ (DCIS) versus invasive breast cancer alone. Anticancer Research 2005; 25: 1719-24.

6. Davidoff AM, Kernes BJ, Iglehard JD, Marks JR. Maintenance of p53 alterations throughout breast cancer progression. Cancer Res 1991; 51: 2605-10.

7. Yamashita H, Nishio M, Toyama T, et al. Coexistence of HER2 over-expression and p53 protein accumulation is a strong prognostic molecular merker in breast cancer. Breast Cancer Res 2004; 6: R24-R30.

8. Xu R, Perle MA, Inghirami G, et al. Amplification of HER-2/neu gene in HER-2/neu-overexpressing and nonexpressing breast carcinomas and their synchronous benign, premalignant, and metastatic lesions detected by FISH in archival material. Mod Pathol 2002; 15: 116-24. 
9. Tsuda H, Hirohashi S. Multiple developmental pathways of highly aggressive breast cancer disclosed by comparison of histological grade and c-erbB-2 expression patterns in both the noninvasive and invasive portions. Pathol Int 1998; 48: 518-25.

10. Hung MC, Lau YK. Basic science of HER-2/neu: a review. Semin Oncol 1999; 26: 51-9.

11. Hockenbery DM, Zutter M, Hickey W, Nahm M, Korsmeyer SJ. Bcl-2 protein is topographically restricted in tissues characterized by apoptotic cell death. Proc Natl Acad Sci U S A 1991; 88: 6961-5.

12. Stewart BW. Mechanisms of apoptosis: integration of genetic, biochemical, and cellular indicators. J Natl Cancer Inst 1994; 86: 1286-96.

13. Leek RD, Kaklamanis L, Pezzella F, Gatter KC, Harris AL. Bcl-2 in normal human breast and carcinoma, association with oestrogen receptor-positive, epidermal growth factor receptor-negative tumours and in situ cancer. Br J Cancer 1994; 69: 135-9.

14. Doglioni C, Dei Tos AP, Laurino L, et al. Bcl-2 expression in breast carcinoma. Mod Pathol 1994; 7: 15A.

15. Mercier I, Gonzales DM, Quann K, et al. CAPER, a novel regulator of human breast cancer progression. Cell Cycle 2014 Apr 15; 13: 1256-64.

16. Mao $\mathrm{Y}, \mathrm{Wu}$ J, Wang $\mathrm{N}$, et al. A comparative study: immunohistochemical detection of cytosolic thymidine kinase and proliferating cell nuclear antigen in breast cancer. Cancer Invest 2002; 20: 922-31.
17. Agarwal S, Jain R, Rusia U, Gupta RL. Proliferating cell nuclear antigen immunostaining in breast carcinoma and its relationship to clinical and pathological variables. Indian J Pathol Microbiol 1997; 40: 11-16.

18. Mack L, Kerkvliet N, Doig G, O'Malley FP. Relationship of a new histological categorization of the ductal carcinoma in situ of the breast with size and the immunohistochemical expression of p53, c-erbB-2, bcl2, and Ki-67. Hum Pathol 1997; 28: 974-9.

19. Holmes P, Lloyd J, Chervoneva, et al. Prognostic markers and long-term outcomes in ductal carcinoma in situ of the breast treated with excision alone. Cancer 2011 Aug 15; 117: 3650-7.

20. Chaisson K, Rivere A, Corsetti R, Weiss T, Fuhrman GM. A potential additional variables to consider in the surgical treatment of ductal carcinoma in situ. Ochsner J 2017 Winter; 17: 341-4.

21. Ioachim EE, Malamau-Mitsi V, Kamina SA, Goussia AC, Agnantis NJ. Immunohistochemical expression of the bcl-2 protein in breast lesions: correlation with Bax, p53, Rb, c-erbB-2, EGFR and proliferation indices. Anticancer Res 2000; 20: 4221-6.

22. Larsen MS, Bjerre K, Giobbie-Hurder A, et al. Prognostic value of $\mathrm{Bcl}-2$ in two independent populations of estrogen receptor positive breast cancer patients treated with adjuvant endocrine therapy. Acta Oncol. 2012 Jul; 51:781-9. 